\title{
A Study on Ways of Evaluating Intelligent Manufacturing Capacity in Domestic Pump Industry
}

\author{
Qi Meng1, a, Deji Hü, b, and Hongyu Shao1,c \\ ${ }^{1}$ Key Laboratory of Mechanism Theory and Equipment Design of Ministry of Education, \\ Tianjin University, No.135,Yaguan Rd., Jinnan District, Tianjin 300354,China \\ ${ }^{2}$ Full Tianjin University of commerce, No.409 Guangrong Rd., Beichen District, Tianjin 300134,China \\ amengqi@tju.edu.cn, bhudeji2000@163.com, cshaohongyu@tju.edu.cn
}

Keywords: Intelligent manufacturing, evaluation system, ways of evaluation

Abstract. In recent years, to develop intelligent manufacturing and lead manufacturing industry to complete reform and industrial upgrading in a benign way has become an important means of promoting our country to join the new round of competition in the global manufacturing industry. Focusing on the evaluation of intelligent manufacturing capacity, the paper sets to offer a comprehensive evaluation from three dimensions, namely technical equipment, manufacturing mode \&management, and intellectual property\&innovation. Under the three dimensions, 6 secondary indicators and 13 tertiary ones are proposed in order to assess the intelligent manufacturing capacity of domestic pump industry in a systematic way. Meanwhile, it also compares domestic pump industry with downstream industries in the industrial chain and provides some suggestions about how to develop intelligent manufacturing in the industry.

\section{Introduction}

Manufacturing industry acts as a pillar industry in our national economy as well as the source power for domestic economic growth. Ever since the eruption of international financial crisis, the manufacturing industry in all the countries across the world have faced such dilemmas as shrinking market demand and reduced yield. The challenges including increasingly high custom demand, shortened delivery period, and low-consumption but high resource utilization rate enforce the manufacturing industry to proceed to the high-end manufacturing direction. In the meantime, the prospering emerging technologies such as cloud computing, big data and web of things shed new light on the development of manufacturing enterprises in the world. In May of 2015, our country issued the medium and long-term development strategy for creating a manufacturing power, namely Made in China 2025, to arrange the implementation of manufacturing power creation strategies by sticking to such principles as innovation-driven, intelligent transformation, strengthened foundation and green development in order to accelerate the transformation of our country from a large manufacturing power to a strong manufacturing power[1]. At present, the intelligent manufacturing is leading a reform of manufacturing methods as well as an industrial upgrading in the industry, and it is elevated to a commanding height amid the new round of manufacturing competition across the world.

The pump is one of the most common devices in general machinery, and the pump-related industries keep developing and prospering. In 2015, the total industrial output value reached 50.34 billion Yuan, an increase of $1.7 \%$ year-on year. The growth rate increased by 0.8 percentage point over the same period of last year[2]. As a matter of fact, a lot of practical problems exist behind the seemingly brilliant pump industry, such as lack of high-end products in domestic market, severe disordered market competition, inferior product performance indicators, and low creativity in independent design[3]. Over 3,000 pump manufacturers in Taizhou of Zhejiang took a lead in proposing a development path to high-end products through intelligent manufacturing in 2013 [4].

An important problem concerning intelligent manufacturing development is how to accurately assess the intelligent manufacturing level. In 2015, the Ministry of Industry and Information Technology and Standard Administration of China jointly published Guideline for National Intelligent Manufacturing Standard System Construction in which it was proposed to "drive intelligent manufacturing with standardization"[5]. In the White Paper about Intelligent 
Manufacturing Capacity and Maturity Model Version 1.0 released by China Electronics Standardization Institute in 2016, the core composition of intelligent manufacturing was explained from two dimensions, namely intelligent and manufacturing, which were further decomposed to be ten core elements for capacity evaluation. Gong Bingzheng[6] developed an evaluation of the intelligent manufacturing in enterprises from ecological environment, development level, and efficacy; Yingfeng[7] proposed some indicators for the intelligent manufacturing evaluation from four levels: production line, workshop/factory, enterprise, and enterprise collaboration; Liu Feng and Ning Jian[8] made a research about the intelligent manufacturing enterprises efficiency evaluation of technological innovation based on EDA; Li Jinfa and Li Biting[9] discussed the evaluation method of R\&D investment value of intelligent manufacturing enterprise based on growth option; Kiwook Jung, Boonserm Kulvatunyou, et al[10] has made an overview of a smart manufacturing system readiness assessment; M Peruzzini, F Gregori, et al[11] took a kitchen sink as example to study the social life cycle assessment methodology for smart manufacturing; L Oneto, I Orlandi, et al[12] researched the performance assessment and uncertainty quantification of predictive models for smart manufacturing systems; as for example verification, Zhang Rongjun, Yu Xiuming et al[13] analyzed the intelligent manufacturing capacity of enterprises in Henan on the basis of some indexes; and Dong Zhixue, Liu Yingji et al[14] employed factor analysis approach to conduct an integrated evaluation and study of the intelligent manufacturing capacity in major provinces and cities of our country.

On basis of the contents above, the paper starts from an analysis of the nature of intelligent manufacturing, establishes an indicator system for the evaluation of intelligent manufacturing capacity, studies the investigation data about the pump industry in our country, and provides some suggestions for the development of intelligent manufacturing in domestic pump industry.

\section{Establishment of intelligent manufacturing capacity evaluation indicator system}

\section{Principles for establishing the evaluation indicator system}

To evaluate the intelligent manufacturing capacity of enterprises requires in-depth analysis of the nature of intelligent manufacturing and definite principles for the establishment of evaluation indicator system.

(1) Intelligent manufacturing is an advanced stage in which the manufacturing industry realizes informatization and integration of IT with industrialization and the whole life cycle of product is covered by automation, informatization, and intellectualization. The evaluation of enterprises' intelligent manufacturing capacity must take into consideration the application of technical equipment investment, high-tech talents, and advanced production technologies.

(2) Intelligent manufacturing is a brand-new mode of manufacturing. In this mode, specific properties and functional demand of products are highlighted. When compared with traditional massive customization, the intelligent manufacturing prefers personalized customization. In order to satisfy the need of new manufacturing mode and the accompanying new management methods, the capacity evaluation also should consider reform and innovation in the manufacturing mode and management methods.

(3) Intelligent manufacturing is driven by data and knowledge. The four networks, namely internet, mobile internet, web of things, and industrial internet, support the network properties of intelligent manufacturing with its core being data and intellectual property. The promotion of big data, user participation in design, and network collaboration enables the enterprises to utilize the data and knowledge about users, suppliers and social resource in a low-cost way. Due attention should be paid to the openness and safety of enterprises. The network collaboration as well as data and knowledge management level should also be enlisted among the evaluation indicators for weighing the intelligent manufacturing level of enterprises.

\section{Establishment of evaluation indicator system}

In light of the principles above, the paper examines the intelligent manufacturing capacity from three perspectives, namely technical equipment, manufacturing mode and innovation in management and intellectual property. Under each primary indicator, there are two secondary indicators. The secondary indicators are further divided into 13 tertiary indicators in total to form the indicator system 
as shown in Table 1. The indicator integration adopts the method of weighted mean. On the basis of expert opinions, the weights of indicators at three levels are determined as indicated in Table 1.

Table 1 Intelligent Manufacturing Capacity Evaluation Indicator System

\begin{tabular}{|c|c|c|c|c|}
\hline $\begin{array}{l}\text { Primary } \\
\text { indicator }\end{array}$ & $\begin{array}{l}\text { Secondary } \\
\text { indicator }\end{array}$ & $\begin{array}{l}\text { Tertiary } \\
\text { indicator }\end{array}$ & $\begin{array}{c}\text { Integrated } \\
\text { weight }\end{array}$ & Explanation \\
\hline \multirow{6}{*}{$\begin{array}{l}\text { Technical } \\
\text { equipment }\end{array}$} & \multirow{2}{*}{$\begin{array}{l}\text { Intelligent } \\
\text { input }\end{array}$} & Equipment & 0.1 & $\begin{array}{l}\text { Input of digital and intelligent production and } \\
\text { processing equipment }\end{array}$ \\
\hline & & Employee & 0.05 & $\begin{array}{l}\text { Percentage and training of high-tech/ } \\
\text { qualification employees }\end{array}$ \\
\hline & \multirow{4}{*}{$\begin{array}{l}\text { Intelligent } \\
\text { equipment }\end{array}$} & Design & 0.05 & $\begin{array}{l}\text { Intelligent level of product design and process } \\
\text { design }\end{array}$ \\
\hline & & Production & 0.15 & $\begin{array}{l}\text { Intelligent level of procurement, planning, } \\
\text { production and quality }\end{array}$ \\
\hline & & Logistics & 0.05 & $\begin{array}{l}\text { Intelligent level of storage, distribution and } \\
\text { logistics transportation }\end{array}$ \\
\hline & & Sales & 1 & Intelligent level of sales and after-sales service \\
\hline \multirow{4}{*}{$\begin{array}{l}\text { Manufacturi } \\
\text { ng mode \& } \\
\text { management }\end{array}$} & \multirow{2}{*}{$\begin{array}{c}\text { Advanced } \\
\text { manufacturing } \\
\text { mode }\end{array}$} & Green service & 0.05 & Green manufacturing and service manufacturing \\
\hline & & Customization & 0.1 & $\begin{array}{l}\text { Massive customization and personalized } \\
\text { customization }\end{array}$ \\
\hline & \multirow{2}{*}{$\begin{array}{l}\text { Management } \\
\text { innovation }\end{array}$} & Organization & 0.05 & $\begin{array}{l}\text { Application of such advanced management } \\
\text { methods as lean management }\end{array}$ \\
\hline & & $\begin{array}{l}\text { Mode } \\
\text { innovation }\end{array}$ & 0.1 & $\begin{array}{l}\text { Reform, adjustment and improvement in ways } \\
\text { of production }\end{array}$ \\
\hline \multirow{3}{*}{$\begin{array}{l}\text { Intellectual } \\
\text { property \& } \\
\text { innovation }\end{array}$} & \multirow{2}{*}{$\begin{array}{l}\text { Knowledge } \\
\text { management }\end{array}$} & Standard & 0.05 & $\begin{array}{l}\text { Accuracy and standardization of data and } \\
\text { knowledge }\end{array}$ \\
\hline & & $\begin{array}{c}\text { Integration and } \\
\text { development }\end{array}$ & 0.05 & $\begin{array}{lcc}\text { Intersystem knowledge integration } & \text { and } \\
\text { beyond-enterprise knowledge utilization } & \end{array}$ \\
\hline & $\begin{array}{l}\text { Collaborated } \\
\text { innovation }\end{array}$ & Collaboration & 0.1 & $\begin{array}{l}\text { Collaborated R\&D and manufacturing in } \\
\text { industrial chain }\end{array}$ \\
\hline
\end{tabular}

\section{Evaluation of domestic pump industry's intelligent manufacturing capacity}

The data in the paper were collected from the 2012-2014 enterprise questionnaire in $12^{\text {th }}$ Five-Year Plan Informatization Sci-tech Project (www.mie-vit.com). Altogether 116 pump-related companies were selected from the enterprises as per their name and primary business. The survey data were mainly provided through options and data filling. The options were set with weights according to the intelligent level while data filling adopted relative benchmarking method with max value being 100 . All the data underwent non-qualified processing and weighted to form indicators. In order to ensure the authenticity of the data filled by the enterprise, redundant verification questions and outlier verification were added. For the options not filled by the enterprises, we first checked the filling rate. When the filling rate was above $80 \%$, interpolation method was used; or the sample would be abandoned.

\section{Indicator analysis}

Based on the integration results of the intelligent manufacturing capacity evaluation indicator system, an analyzing diagram of the tertiary evaluation indicators for intelligent manufacturing of domestic pump industry in 2015 was prepared (see Fig. 1). The average score of 13 tertiary indicators was 0.4008 , with max value being 0.5777 in equipment and min value being 0.2033 in collaboration.

Judging from the diagrams, we can find that the mode innovation management, intersystem integration and development, and industrial chain collaboration got relatively low scoring, proving that the pump industry was not prominent in such aspects. An investigation into the interconnection and inter-operation concerning different business and systems within the enterprises reveals that by now what most of the enterprises can do is limited to the integrated operation of small-scale production, supply chain and R\&D and design around the core production process, and difficulty still 
remains for the enterprises to realize business integration between upstream and downstream of the industrial chain, or even among enterprises on the cloud platform. Also, it still needs a lot of efforts to use the informatization means and intelligent management measures under the driving force of network in re-thinking about constructing new production modes and organization ways. At present, the much-emphasized aspects as personalized customization, remote operation and maintenance, and collaborated manufacturing are not effectively realized in the pump industry yet.

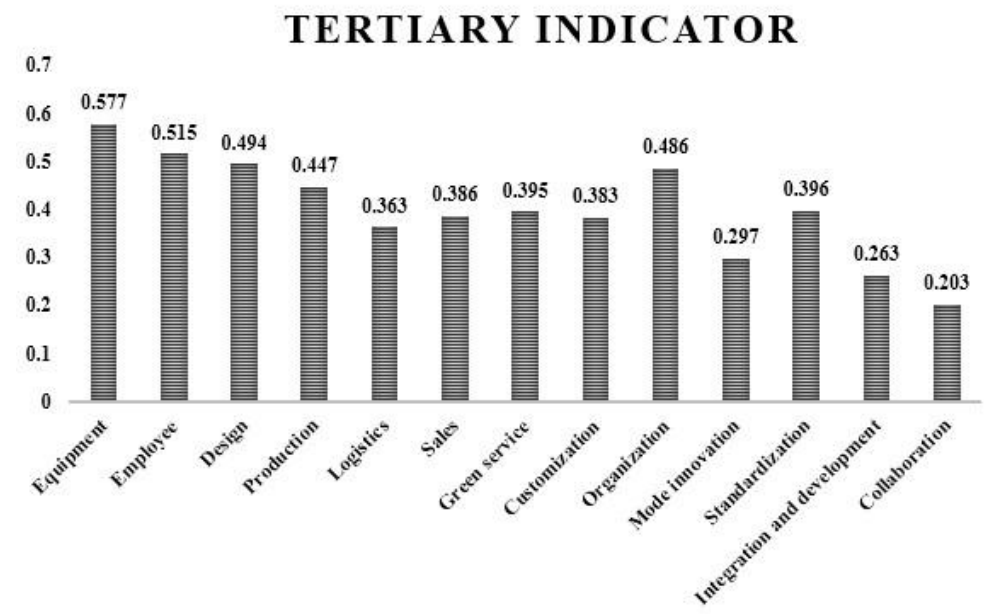

Fig. 1 Tertiary indicator scoring diagram

\section{Industrial comparison}

We also made use of the data of 2012-2014 in $12^{\text {th }}$ Five-Year Plan Informatization Sci-tech Project to analyze the intelligent manufacturing capacity of the downstream industries of the pump, such as engine and hydroelectric machine, and formed indicator-based industrial comparison diagrams (see Fig. 2 and 3). Through calculation, the average evaluation score of pump industry was 0.3806 while that of downstream industries was 0.4208 between which no significant difference can be spotted. However, a comparison of the tertiary indicators suggests that the pump industry still lags far behind its upstream and downstream industries in the employee, production, integration and development, and collaboration.

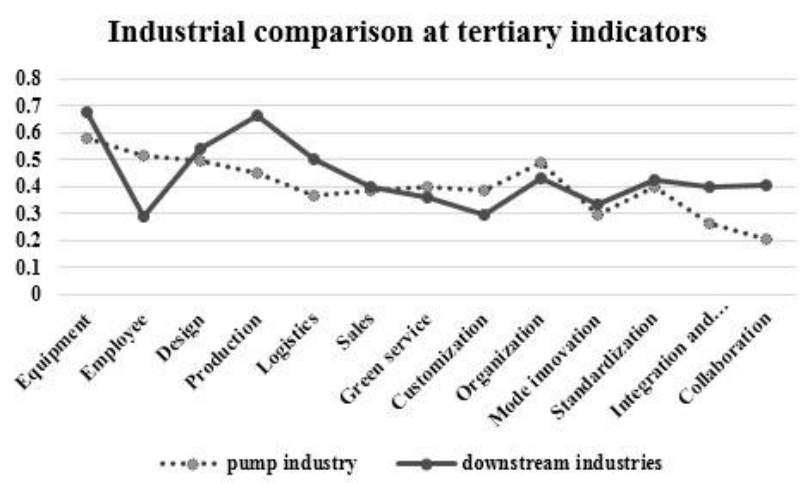

Fig. 2 Industrial comparison at tertiary indicators

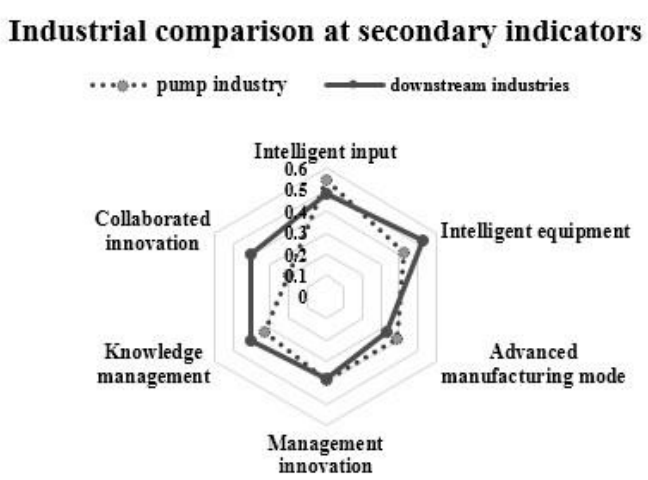

Fig. 3 Industrial comparison at secondary indicators

It can be more clearly seen from the secondary indicator comparison diagram that the radar radiation of downstream industries is more even and all the indicators have higher coefficients. By comparison, the pump industry is slightly insufficient in the intelligent equipment and intellectual management, especially in the collaborated innovation. It means the pump industry is not closely collaborative with its upstream and downstream enterprises, and it fails to realize sharing and innovation in the inter-enterprise innovation resource, design capacity and productivity.

\section{Conclusions}

1. Through construction the intelligent manufacturing capacity evaluation system, the paper digitally measures the intelligent level of enterprises in our pump industry in the present 
manufacturing mode, determines the insufficiency of the pump industry in business management, system integration and collaborated innovation, especially when compared with the downstream industries.

2. Whilst flexible production and personalized customization are becoming the mainstream development trend, the pump manufacturers should actively join in the reform in the industrial chain, carry out innovation and develop towards massive customization and service manufacturing to provide the clients with high-end customized products that better suit clients' demand.

3. The pump manufacturers should also take a lead in applying the new technologies such as computer simulation, VR, web of things, 3D printing, and industrial big data, pay attention to knowledge accumulation and effective intellectual management, and gradually form the new competition mode with intellectual property as the core part.

\section{Acknowledgements}

This work was financially supported by the Tianjin Science and Technology Special Commissioner Project (16JCTPJC48300), Major Program of China Social Science Foundation (16AZD004).

\section{References}

[1] China Electronics Standardization Institute. White Paper about Intelligent Manufacturing Capacity and Maturity Model Version 1.0[R]. Beijing,2016

[2] Analysis of enterprise economic operation in pump industry in 2016 [OL]. http://www.chyxx. com/ industry/ 201609/451007.html,2016,9,22

[3] He Xijie, Lao Xuesu. An overview of pump market development in China[J]. Information of China Construction(Water-Industry Market),2009,10:8-12

[4] Cui Yuping.Tangible hand boost the Daxi pumo enterprises to upgrade[J]. China Industry News, 2013,1:1-2

[5] Ministry of Industry and Information Technology and Standard Administration of China. Guideline for National Intelligent Manufacturing Standard System Construction[R]. Beijing, 2015

[6] Gong Bingzheng. The discussion on evaluation index and the assessment method of intelligent manufacturing[J]. Application of Electronic Technique, 2015,41(11):6-8

[7] Feng Yin. Study on Evaluating Indicator System of Smart Manufacutring[J]. Industrial Economy Review, 2016,11:632-641

[8] Liu Feng, Ning Jian. Intelligent Manufacturing Enterprises Efficiency Evaluation of Technological Innovation: Research Based on DEA [J]. Atlantis Press, 2015:149-154

[9] Li Jinfa, Li Biting. Evaluation Method of R\&D Investment Value of Intelligent Manufacturing Enterprise Based on Growth Option[J]. Procedia Engineering,2017,1:301-307

[10] Kiwook Jung, Boonserm Kulvatunyou, et al. An Overview of a Smart Manufacturing System Readiness Assessment[J]. Advances in Production Management Systems, 2016,3:705-712

[11] M Peruzzini, F Gregori, et al, A social life cycle assessment methodology for smart manufacturing: the case of study of a kitchen $\sin k[\mathrm{~J}]$. Journal of Industrial Information Integration, 2017.4

[12] L Oneto, I Orlandi, et al. Performance assessment and uncertainty quantification of predictive models for smart manufacturing systems[J]. IEEE International Conference on Big Data, 2015:1436-1445

[13] ZHANG Rong-jun, YU Xiu-ming, et al. Intelligent Manufacturing Capacities Analysis of Enterprises in Henan Province Based on Intelligent Manufacturing Evaluation Indexes[J]. Standard Science, 2016,7:24-27

[14] Dong Zhixue, Liu Yingji. Comprehensive evaluation and research on the intelligent manufacturing capability of the main provinces and cities in China-Empirical analysis based on factor analysis method. Modern Manufacturing Engineering, 2016,1:151-158 